Response to: 'Response to: 'Alcohol is not the missing link between Porphyromonas gingivalis related periodontitis and radiologic progression in early Rheumatoid arthritis' by Hillion et al' by Marotte and Paul

We thank Marotte et $a l^{1}$ for their interest in our study. ${ }^{2}$ They suggested to check interactions between Porphyromonas gingivalis serology, smoking and human leucocyte antigen (HLA) status as in the Etude et Suivi des Polyarthrites Indifférenciées Récentes (ESPOIR) cohort and the association between P. gingivalis serology status and radiological progression. In the ESPOIR cohort, $P$. gingivalis serology was increased in patients who are non-smokers and with structural damage. ${ }^{3}$

As suggested, we checked interactions with smoking and HLA status. We could not find any significant interaction between alcohol intake, $P$. gingivalis serology and structural progression in the non-smoking population (table 1). We also ran a multivariate analysis showing that shared epitope ${ }^{4}$ alcohol intake and $P$. gingivalis serology are not independently associated with structural progression in patient with early RA of ESPOIR cohort (table 2).

Hence, in the ESPOIR cohort, we could not show any influence of $P$. gingivalis serology on structural progression, even in the non-smoking population of early rheumatoid arthritis.

\author{
Alexandre Bellier, ${ }^{1}$ Xavier Romand, ${ }^{2}$ Athan Baillet ${ }^{2}{ }^{2}$ \\ 'Unité de Qualité et d'Evaluation Médicale, CHU Grenoble Alpes, La Tronche, \\ Grenoble, France \\ ${ }^{2}$ Univ Grenoble Alpes, CNRS, CHU Grenoble Alpes, Grenoble INP, TIMC-IMAG, \\ Grenoble, France
}

Correspondence to Professor Athan Baillet, Univ.Grenoble Alpes, CNRS, CHU Grenoble Alpes, Grenoble 38000, France; abaillet@chu-grenoble.fr

Collaborators We also wish to thank Nathalie Rincheval (CHU Montpellier and EA 2415) who did expert monitoring and data management and all the investigators who recruited and followed the patients (F Berenbaum, Paris-Saint Antoine; MC Boissier, Paris-Bobigny; A Cantagrel, Toulouse; B Combe, Montpellier; M Dougados, Paris-Cochin; P Fardelone, P Boumier Amiens, B Fautrel, Paris-La Pitié; RM Flipo, Lille; Ph Goupille, Tours; F Liote, Paris-Lariboisière; O Vittecoq, Rouen; X Mariette, Paris Bicetre; 0 Meyer and Ph Dieude, Paris Bichat; A Saraux, Brest; Th Schaeverbeke, Bordeaux; I Sibilia, Strasbourg), V Devauchelle and C Lukas for expert X-ray reading and S Martin (Paris Bichat) who did all the central dosages of CRP, IgA and IgM rheumatoid factor and anti-CCP antibodies.
Table 2 Porphyromonas gingivalis serology is not an independent predictor of structural progression in the multivariate logistic regression results

\begin{tabular}{llr}
\hline & OR $(95 \% \mathrm{Cl})$ & P value \\
\hline Model 1 & & \\
Smoking status & $0.87(0.64$ to 1.26$)$ & 0.359 \\
Age & $1.04(1.02$ to 1.05$)$ & $<0.001$ \\
Gender & $0.75(0.50$ to 1.10$)$ & 0.157 \\
P. gingivalis serology & $0.75(0.47$ to 1.21$)$ & 0.235 \\
HLA-DRB1 genotype* & $1.46(0.95$ to 2.23$)$ & 0.078 \\
Model 2 & & \\
Smoking status & $0.81(0.59$ to 1.11$)$ & 0.197 \\
Age & $1.05(1.03$ to 1.07$)$ & $<0.001$ \\
Gender & $0.74(0.48$ to 1.11$)$ & 0.156 \\
P. gingivalis serology & $0.74(0.46$ to 1.22$)$ & 0.231 \\
HLA-DRB1 genotype & $0.86(0.53$ to 1.40$)$ & 0.550 \\
Alcohol intake & $1.16(0.75$ to 1.87$)$ & 0.520 \\
Baseline DAS28 & $1.03(0.86$ to 1.23$)$ & 0.756 \\
Rheumatoid factor & $1.14(0.78$ to 1.67$)$ & 0.499 \\
ACPA & $2.26(1.49$ to 3.47$)$ & $<0.001$ \\
\hline P. &
\end{tabular}

$P$. gingivalis antibodies were measured using a homemade ELISA as previously described. ${ }^{2}$ Patients were considered $P$. gingivalis positive when their anti- $P$. gingivalis antibody titre was above the higher quartile.

Radiological progression was defined as a progression $\geq 1$ point/year of modified Sharp/van der Heijde score within the first 5 years of follow-up.

*Shared epitope alleles were HLA-DRB1 *0101, *0102, *0401, *0404, *0405, ${ }^{*} 0408,{ }^{*} 0410$, and ${ }^{*} 1001 .{ }^{3}$

ACPA, anticitrullinated protein antibody; DAS28, Disease Activity Score 28 joints; HLA, human leucocyte antigen.

Contributors $X R$ and $A B$ critically reviewed the study proposal and critically reviewed the study proposal; $A B$ generated statistical analysis and critically reviewed the study proposal.

Funding This study was funded by Direction de la Recherche Clinique Grenoble. Competing interests None declared.

Patient consent for publication Not required.

Provenance and peer review Not commissioned; internally peer reviewed.

(C) Author(s) (or their employer(s)) 2020. No commercial re-use. See rights and permissions. Published by BMJ.

Check for updates

Table 1 Interactions between gender, Porphyromonas gingivalis infection and radiological progression of American College of Rheumatology/ European League Against Rheumatism 2010 patients with early rheumatoid arthritis in the ESPOIR cohort

\begin{tabular}{|c|c|c|c|c|c|}
\hline$N=533$ & & Non-smoking $(\mathrm{N}=287)$ & Smoking (N=246) & OR $(95 \% \mathrm{Cl})$, p value & \\
\hline \multirow{2}{*}{$\begin{array}{l}\text { Negative } P \text {. gingivalis } \\
\text { serology }(\mathrm{N}=399)\end{array}$} & No radiological progression & $43(8)$ & $45(8)$ & 0.79 (0.49 to 1.27$), 0.336$ & 0.94 (0.63 to 1.40$), 0.763$ \\
\hline & Radiological progression & $170(32)$ & $141(27)$ & & \\
\hline \multirow{2}{*}{$\begin{array}{l}\text { Positive } P \text {. gingivalis serology } \\
(\mathrm{N}=133)\end{array}$} & No radiological progression & $19(4)$ & $17(3)$ & 0.90 (0.41 to 0.77$), 0.767$ & \\
\hline & Radiological progression & $54(10)$ & $43(8)$ & & \\
\hline \multicolumn{6}{|c|}{ Mantel-Haenszel test, $p=0.384$} \\
\hline \multirow[t]{2}{*}{ Men $(N=116)$} & No radiological progression & $9(2)$ & $11(2)$ & $1.8(0.67$ to 4.80$), 0.238$ & $0.34(0.22$ to 0.53$),<0.001$ \\
\hline & Radiological progression & $30(6)$ & $66(12)$ & & \\
\hline \multirow[t]{2}{*}{ Women $(\mathrm{N}=417)$} & No radiological progression & $53(10)$ & $51(10)$ & 0.62 (0.40 to 0.98$), 0.042$ & \\
\hline & Radiological progression & $195(36)$ & $118(22)$ & & \\
\hline \multicolumn{6}{|c|}{ Mantel-Haenszel test, $\mathrm{p}=0.201$} \\
\hline
\end{tabular}


To cite Bellier A, Romand X, Baillet A. Ann Rheum Dis 2020;79:e109.

Received 29 June 2019

Revised 9 July 2019

Accepted 9 July 2019

Published Online First 31 July 2019

\section{S Linked}

http://dx.doi.org/10.1136/annrheumdis-2019-215731

- http://dx.doi.org/10.1136/annrheumdis-2019-215603

Ann Rheum Dis 2020;79:e109. doi:10.1136/annrheumdis-2019-215962

ORCID iD

Athan Baillet http://orcid.org/0000-0001-6006-2519
REFERENCES

1 Marotte H, Paul S. Response to: 'Alcohol is not the missing link between Porphyromonas gingivalis related periodontitis and radiologic progression in early Rheumatoid arthritis' by Hillion et al. Ann Rheum Dis 2020;79:e108.

2 Hillion J, Bellier A, Romand X, et al. Alcohol is not the missing link between Porphyromonasgingivalis-related periodontitis and radiological progression in early rheumatoid arthritis: comment on 'Porphyromonas gingivalis experimentally induces periodontitis and an anti-CCP2-associated arthritis in the rat'. Ann Rheum Dis 2020;79:e107.

3 Seror R, Le Gall-David S, Bonnaure-Mallet M, et al. Association of Anti-Porphyromonas gingivalis antibody titers with nonsmoking status in early rheumatoid arthritis: results from the prospective French cohort of patients with early rheumatoid arthritis. Arthritis Rheumatol 2015;67:1729-37.

4 Baillet A, Gossec L, Paternotte S, et al. Evaluation of serum interleukin-6 level as a surrogate marker of synovial inflammation and as a factor of structural progression in early rheumatoid arthritis: results from a French national multicenter cohort. Arthritis Care Res 2015;67:905-12. 